\title{
A New Cationic Liposome DNA Complex Enhances the Efficiency of Arterial Gene Transfer In Vivo
}

\author{
DOMINIQUE J. STEPHAN, ${ }^{1}$ ZHI-YONG YANG, ${ }^{1,2}$ HONG SAN, ${ }^{1}$ ROBERT D. SIMARI, ${ }^{1}$ \\ CARL J. WHEELER, ${ }^{3}$ PHILIP L. FELGNER,${ }^{3}$ DAVID GORDON, ${ }^{4}$ GARY J. NABEL $,, 2,5$ and \\ ELIZABETH G. NABEL ${ }^{1,6}$
}

\begin{abstract}
An important goal of gene therapy for cardiovascular diseases and cancer is the development of effective vectors for catheter-based gene delivery. Although adenoviral vectors have proven effective for this purpose in animal models, the ability to achieve comparable gene transfer with nonviral vectors would provide potentially desirable safety and toxicity features for clinical studies. In this report, we describe the use of a new cationic DNA-liposome complex using an improved expression vector and lipid, $N$-(3-aminopropyl)$\boldsymbol{N}, \boldsymbol{N}$-dimethyl-2,3-bis(dodecyloxy)-1-propaniminium bromide/dioleoyl phosphatidylethanolamine (GAP-DLRIE/DOPE) to optimize catheter-mediated gene transfer in porcine arteries. The efficiency of this vector was compared to DNA alone, DNA with a previously described cationic liposome complex, ( \pm )- $N$-(2-hydroxyethyl)- $N, N$-dimethyl-2,3-bis(tetradecyloxy)-1-propanaminium bromide (DMRIE/DOPE), and a replicationdefective adenoviral vector in a porcine artery gene transfer model. When used in optimal ratios, GAP-DLRIE/DOPE liposomes provided a 15-fold higher level of gene expression in arteries compared to DNA alone or DMRIE/DOPE. Gene expression was observed in intimal and medial cells. However, when compared to adenoviral vectors $\left(10^{10} \mathrm{pfu} / \mathrm{ml}\right)$, gene expression following GAP-DLRIE/DOPE transfection was $\sim 20$-fold lower. Following intravenous injection of GAP-DLRIE/DOPE in mice, biochemical, hematological, and histopathological abnormalities were not observed. Significant improvements in the efficacy of arterial gene expression can be achieved by optimization of transfection conditions with DNA-liposome complexes in vivo that may prove useful for arterial gene delivery in cardiovascular diseases and cancer.
\end{abstract}

\section{OVERVIEW SUMMARY}

GAP-DLRIE/DOPE, a new cationic liposome preparation, is an efficient liposomal vector that increases gene expression in arteries compared to naked DNA or previously described cationic DNA-liposome complexes by more than 15 fold. Although less efficient than adenoviral gene transfer, these levels of gene expression represent a significant improvement in liposome transfection in vivo and approach levels observed with clinically acceptable doses of adenoviral vectors. The improvement in gene expression, together with the relative safety associated with liposomal gene transfer, suggests that such nonviral vectors may be appropriate for human gene therapy protocols which utilize catheterbased gene delivery.

\section{INTRODUCTION}

Cene transfer into the arterial wall has the potential to alter the biological response of vascular cells to growth stimulation, lipid accumulation, coagulation, and inflammation, all of which may contribute to the development of cardiovascular diseases. Large arteries also provide access to microvessels of organs and malignant neoplasms for recombinant gene transfer. An important objective of arterial gene transfer is the development of effective vectors that optimize gene expression and minimize toxicity. Previous studies have demonstrated the feasibility of arterial gene delivery in vivo with viral and nonviral vectors (for review, see Nabel, 1995). Side-by-side comparisons of nonviral and viral vectors have not been made, and it is currently accepted that adenoviral vectors result in higher

Departments of ${ }^{1}$ Internal Medicine, ${ }^{4}$ Pathology, ${ }^{5}$ Biological Chemistry, and ${ }^{6}$ Physiology and ${ }^{2}$ Howard Hughes Medical Institute, University of Michigan, Ann Arbor, MI 48109-0644.

${ }^{3}$ Vical Inc., San Diego, CA 92121. 
levels of gene expression in vivo compared with nonviral vectors. Although adenoviral vectors are efficient vectors, studies have suggested a greater potential for local and systemic toxicities in some organs, like the lung (Simon et al., 1993), particularly at the high concentrations often needed for optimal efficacy. This concern has been highlighted recently in human gene therapy protocols for cystic fibrosis (Knowles et al., 1995). An attractive, alternative approach to gene delivery to arteries is cationic DNA-liposome complexes (Nabel et al., 1990; Chapman et al., 1992). These vectors have been employed in preclinical animal models and clinical gene therapy studies in diverse cell types, including those in the vasculature (Leclerc et al., 1992; E. Nabel et al., 1993; Shi et al., 1994; Muller et al., 1994), airway epithelium (Caplen et al., 1994), and tumors (G. Nabel et al., 1993).

Several features of these nonviral vectors are attractive for gene transfer studies, including their relative safety and lack of toxicity. However, a limitation of these vectors has been a relative inefficiency of gene transfer. In this study, we describe the application of a cationic lipid, GAP-DLRIE/DOPE, for arterial gene transfer in vivo. Studies were performed to determine optimal DNA:lipid ratios and concentrations for gene transfer in vivo and to compare its efficiency to DNA alone, other cationic lipids, and adenoviral vectors. The safety and toxicity of this lipid formulation was also analyzed in vivo after systemic intravenous injection in mice. Here, we describe substantial improvements in transgene expression with cationic DNA-liposome complexes that may improve their utility for catheter-based gene delivery.

\section{MATERIALS AND METHODS}

\section{Plasmid expression vectors and cationic lipids}

A eukaryotic expression vector plasmid encoding a chloramphenicol acetyl transferase (CAT) gene under the control of a cytomegalovirus promoter and enhancer, pCMV-CAT, was used for in vivo experiments. This plasmid contains a $5^{\prime}$ untranslated region and intron sequences from the CMV immediate early gene downstream of the promoter and a bovine growth hormone polyadenylation signal (Manthorpe et al., 1993). A plasmid expression vector encoding a heat-stable human placental alkaline phosphatase (hpAP) gene was constructed using the same plasmid backbone (VR1012), pCMV-hpAP. The blunted Hind III, Pst I hpAP fragment from pBlueScript was cloned in the blunted Sal I site of VR 1012. Plasmid DNA was prepared by column chromatography (Horn et al., 1995; Lew et al., 1995) and kindly supplied by Vical, Inc. For the highest concentration of plasmid DNA used, the maximum total endotoxin was $\sim 240 \mathrm{Eu}$.

For in vivo, experiments, the following experimental groups were studied: (i) plasmid DNA alone with no vector: (ii) plasmid DNA complexed with DMRIE/DOPE; and (iii) plasmid DNA complexed with GAP-DLRIE/DOPE. DMRIE/DOPE was prepared as previously described (Wheeler et al., 1996). GAP-DLRIE/DOPE is ( \pm )- $N$-(3-aminopropyl)- $N, N$-dimethyl2, 3-(bis-dodecyloxy)-1-propaniminium bromide, complexed in a 1:1 mole:mole mixture with DOPE, - $\alpha$-dioleoyl phosphatidylethanolamine (Felgner et al., 1994). GAP-DLRIE is a member of the 2,3-dioxy-propaniminium class of cationic lipids, which includes DMRIE, DOTAP, DOTMA, and DOSPA. This class of cytofectins has two hydrophobic chains appended to a quaternary ammonium moiety via a polar dioxypropyl group. The lipophilic region of GAP-DLRIE is comprised of two linear, fully saturated 12-carbon alkyl chains, and the quaternary ammonium group bears a propylamino substitution. Transfection efficiency of the 2,3-dioxy propaniminium class of cationic lipids is enhanced by admixing with DOPE.

To determine the optimal ratios of GAP-DLRIE/DOPE to plasmid DNA, pCMV-CAT was complexed with GAPDLRIE/DOPE at increasing concentrations of $6.25 \mu \mathrm{g} / \mathrm{ml}$ to $600 \mu \mathrm{g} / \mathrm{ml}(20.15$ to $1613 \mu M)$ whereas the DNA was held constant. To quantitate the stoichiometry of cationic lipid and DNA interaction, the molar ratio of cationic lipid to nucleotide, rather than cationic lipid to plasmid, was calculated based on the molecular weight of a single nucleotide (310 grams/mole). Likewise, to assess the optimal concentrations of GAP-DLRIE/DOPE, the lipid was complexed with plasmid DNA at increasing concentrations of $105,158,316$, and 526 $\mu M$, whereas the DNA concentration was held constant at 125 $\mu \mathrm{g} / \mathrm{ml}(404 \mu M)$ to yield progressively increasing cationic lipid/DNA ratios of $0.26,0.39,0.78$, and 1.3 molar. Once an optimal ratio of GAP-DLRIE/DOPE:DNA was chosen, the absolute concentration of cationic lipid:nucleotide was held constant and increasing concentrations of DNA from 6.25 to 600 $\mu \mathrm{g} / \mathrm{ml}(20.15$ to $1613 \mu M$ ) were tested. The pCMV-CAT expression vector was used to determine optimal ratios and concentrations for arterial gene transfer. The pCMV-hpAP vector was used to determine cellular localization of the transgene following arterial gene transfer. DMRIE/DOPE (310 $\mu M)$ complexed with DNA (403 $\mu M, 125 \mu \mathrm{g} / \mathrm{ml}$ ), which had been previously optimized in endothelial and smooth muscle cells in vivo (San et al., 1993), and plasmid DNA (806 $\mu M, 250$ $\mu \mathrm{g} / \mathrm{ml}$ ) in the absence of lipid was compared to the optimal formulation of GAP-DLRIE/DOPE:DNA. For preparation of cationic liposome-DNA complexes, DNA was diluted in 0.4 $\mathrm{ml}$ of Opti-MEM (GIBCO, BRL) at room temperature. GAPDLRIE/DOPE was resuspended in sterile water, then diluted in $0.4 \mathrm{ml}$ of Opti-MEM. The lipids were added to DNA by gentle mixing. DMRIE/DOPE was complexed with DNA in lactated Ringer's solution as previously described (San et al., 1993). For in vivo toxicity studies, a plasmid encoding HLAB7 and $\beta_{2}$ microglobulin (G. Nabel et al., 1993) under control of the Rous sarcoma virus long terminal repeat was used. For the toxicity studies in mice, GAP-DLRIE/DOPE:DNA complexes were prepared by mixing plasmid DNA $(10 \mu \mathrm{g})$ with GAP-DLRIE/DOPE $(30 \mu \mathrm{g})$ in a final volume of $0.1 \mathrm{ml}$ of Ringer's solution before injection into the tail vein.

\section{Adenoviral vectors}

A recombinant adenoviral vector, ADV-CAT, was constructed by homologous recombination between sub360 genomic DNA, an Ad-5 derivative, and a CAT expression plasmid, pAd-CAT, which contains the same regulatory elements as the pCMV-CAT plasmid used for liposomal transfection studies. The pAd-CAT plasmid was prepared by ligating a $M s c$ I-Xmm I fragment from the pCMV-CAT expression vector into the $B g l$ II site of a pAd-Bgl II plasmid. Human embryonic kid- 
ney 293 cells were co-transfected with $10 \mu \mathrm{g}$ of the Nhe I-digested pAd-CAT and $1 \mu \mathrm{g}$ of Cla I and Xba l-digested sub360 DNA. Infectious viruses were isolated by plaque assay, and plaques containing recombinant adenovirus were screened for CAT activity. The structure of the virus was confirmed by Southern blot analysis. The recombinant virus was propagated in 293 cells and purified as described (Davidson et al., 1993). Cesium chloride-purified virus was dialyzed against phosphatebuffered saline (PBS) and diluted for storage in 13\% glycerolPBS solution to yield a final concentration of $10^{12}$ viral particles/ml $\left[10^{10}\right.$ plaque forming units $(\mathrm{pfu}) / \mathrm{ml}$, determined by plaque assays]. All stocks were sterilized with a $0.45-\mu M$ filter and evaluated for the presence of replication-competent adenovirus by infection at a multiplicity of infection (moi) of 10 onto 3T3 cells. None of the stocks used in these experiments yielded replication-competent virus.

\section{In vivo gene transfer}

Male and female Yorkshire pigs $(n=33)$ were used for in vivo experiments. Arterial gene transfer was performed in the right and left iliofemoral arteries of each pig as described (Nabel et al., 1990). Briefly, after anesthesia, the right and left iliofemoral arteries were exposed by surgical technique, and a double-balloon catheter (USCI, Billerica, MA) was positioned in each artery. Gene transfer was performed into injured arteries $(n=59)$, noninjured arteries $(n=6)$, and saline alone was infused in one injured artery as a control. Gene transfer into injured arteries is a standard animal model of vascular gene transfer for primary vascular diseases, such as atherosclerosis or restenosis (Ohno et al., 1994; Chang et al., 1995a). Gene transfer into noninjured arteries might be performed in a clinical setting, such as cancer gene therapy, to treat lesions withm an organ by catheter-mediated gene delivery (Nabel et al., 1994).

Arterial injury was performed by positioning the distal balloon in the arterial site to be injured and inflating the balloon to $500 \mathrm{mmHg}$ for $1 \mathrm{~mm}$. The balloon was deflated, and the catheter was repositioned such that the central portion of the catheter between the two balloons straddles the injured area of the artery (Simari et al., 1996b). In both injured and noninjured arteries, the arterial segment was flushed with the vector solution $(0.8 \mathrm{ml})$, and both the proximal and distal balloons were inflated. The vector solution was instilled into the site of injury for $20 \mathrm{~mm}$ at $150 \mathrm{mmHg}$. Following instillation, the catheter was removed, and the animal recovered. Liposomal gene transfer was performed in 49 arteries, DNA alone was infused into seven arteries, and adenoviral gene transfer was conducted in three arteries using viral titers of $1 \times 10^{10} \mathrm{pfu} / \mathrm{ml}$ (total dose of $7 \times 10^{9} \mathrm{pfu}$ ). Saline alone was infused into the central portion of the double-balloon catheter after balloon injury in one artery. Liposome gene transfer was performed into six noninjured arteries.

Animals were sacrificed $48 \mathrm{hr}$ later. Following anesthesia, the artery segment between the two balloons was removed. Each artery sample $(1 \mathrm{~cm})$ was processed in an analogous manner by serial section into three rings. The middle section was fixed in $10 \%$ buffered formaldehyde, embedded in paraffin, and stained with hematoxylin and eosin. The proximal and distal sections were processed for protein extraction and measurement of CAT activity. All animal studies were performed within the guide- lines of the National Institutes of Health and with the approval of the University of Michigan Committee on the Use and Care of Animals.

\section{CAT assay}

Detection of CAT activity was performed as previously described (Gorman et al., 1982). Forty-eight hours after transfection, the arteries were removed. Tissues were crushed using a glass pestle, then frozen and thawed three times. The samples were incubated $10 \mathrm{~min}$ at $65^{\circ} \mathrm{C}$ to mactivate deacetylase. Proteins were extracted and quantified by means of a colorimetric assay (Bio-Rad, Hercules, CA). Ten to $200 \mu \mathrm{g}$ of protein from each artery was assayed for CAT activity during a 4$\mathrm{hr}$ incubation period.

\section{Histochemistry, immunohistochemistry, and morphometry}

Expression of recombinant hpAP protein was detected by histochemical analysis of transfected arteries (Pompili et al., 1995). Formalin-fixed, paraffin-embedded specimens were sectioned, placed in phosphate-buffered saline (PBS) at $65^{\circ} \mathrm{C}$ for $60 \mathrm{~min}$ to inactivate endogenous alkaline phosphatase, and incubated in a chromogenic substrate consisting of 5-bromo-4chloro-3-indolyl phosphate $p$-toluidine $(1 \mathrm{mg} / \mathrm{ml})$ and nitro blue tetrazolium chloride for $19 \mathrm{hr}$. Sections were counterstained

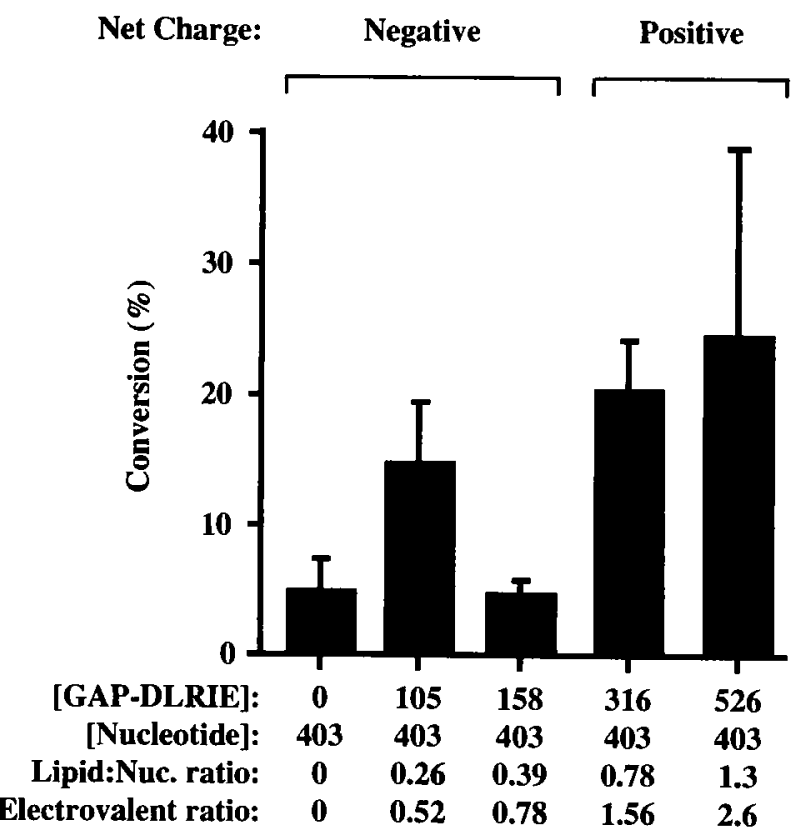

FIG. 1. Gene expression in porcine arteries after transfection with a constant amount of pCMV-CAT plasmid DNA and increasing lipid/nucleotide ratios. Plasmid DNA, $403 \mu M$ nucleotide $(125 \mu \mathrm{g} / \mathrm{ml})$, was incubated with $105 \mu M(125 \mu \mathrm{g} / \mathrm{ml}$, $n=5$ arteries), $158 \mu M$ (187.5 $\mu \mathrm{g} / \mathrm{ml}, n=4$ arteries), $316 \mu M$ $(375 \mu \mathrm{g} / \mathrm{ml}, n=6$ arteries $)$, and $526 \mu M(625 \mu \mathrm{g} / \mathrm{ml}, n=3$ arteries) of GAP-DLRIE, giving the indicated molar ratios of cationic lipid to nucleotide (Lipid:Nuc. ratio:) and charge ratio of lipid to nucleotide (Electrovalent ratio:). Naked DNA at the same concentration is included in comparison. Overall charge of the cationic DNA-liposome complex is shown above. Concentrations of lipid and nucleotide are indicated in $\mu M$. 
A.

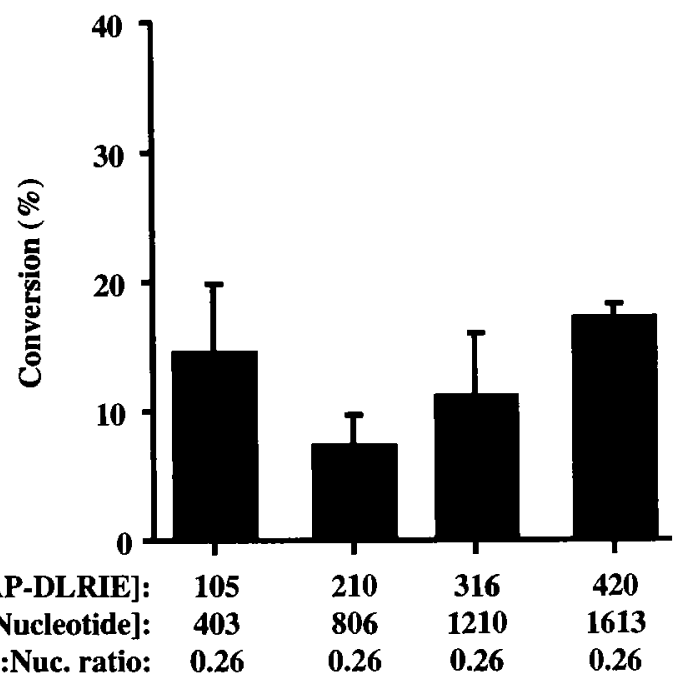

B.

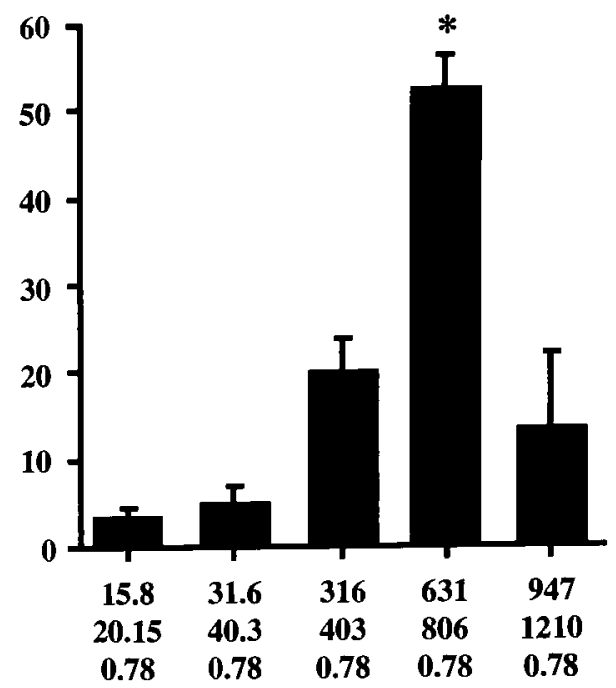

FIG. 2. Reporter gene expression in porcine arteries with 0.26 (A) or 0.78 (B) molar ratio of GAP-DLRIE/DOPE:nucleotide and increasing concentrations of DNA-liposome complex. Concentrations of lipid and nucleotide $(\mu M)$ are shown. $n=3-6$ arteries at each lipid/nucleotide ratio. ${ }^{*} p<0.01$, ANOVA with the Scheffe test.

with methylene green. Immunohistochemical studies were performed to identify endothelial cells [monoclonal goat antihuman von Willebrand's factor (vWf) antibody, 1:10,000 dilution, Atlantic Antibodies] and smooth muscle cells (monoclonal mouse anti-smooth muscle $\alpha$-actin antibody, 1:500 dilution, Boehringer Mannheim Biochemical) as previously described (Pompili et al., 1995). Measurements of transfection efficiency were made by counting the number of alkaline phosphatasepositive cells and the total number of cells in the intima, media, and adventitia of arteries using a microscope-based video image analysis system (Image One Systems, Universal Imaging Corp.) as described (Pompili et al., 1995).

\section{Toxicity studies}

Intravenous injections were carried out via the tail vein using a 21-gauge needle in 24 adult female mice (strain BALB/c) to evaluate the tissues and systemic effects of GAP DLRIE/DOPE and DNA. For intravenous injections, GAP DLRIE/DOPE (30 $\mu \mathrm{g})$ and PCMV-CAT or HLA-B7 plasmid DNA $(10 \mu \mathrm{g})$ were mixed in a final volume of $0.1 \mathrm{ml}$ of Ringer's solution immediately prior to injection. Three groups were studied. In group 1, a single tail vein injection was given ( $n=4$ mice). Animals were sacrificed 4 days later, and heart, lung, kidney, and spleen were analyzed for percent CAT conversion. In group 2, a single tail vein injection was given ( $n=$ 10 mice). Animals were sacrificed 2 weeks later. Blood was collected pretreatment and at sacrifice and analyzed biochemically. Organs (brain, lung, heart, liver, kidney) were removed at 2 weeks for histopathology analysis. In group 3, a single tail vein injection was given at 2-week intervals for a total of three injections over 6 weeks, and animals were sacrificed at 6 weeks $(n=10$ mice). Blood was collected before treatment and 6 weeks later for biochemical analysis. Organs were removed at 6 weeks and analyzed by histology.

\section{Statistics}

Results are expressed as a mean and standard error of the mean ( \pm SEM). Each artery was treated as an independent observation. The mean of each treatment group was compared by an unpaired two-tailed Student's $t$-test or by an analysis of vari-

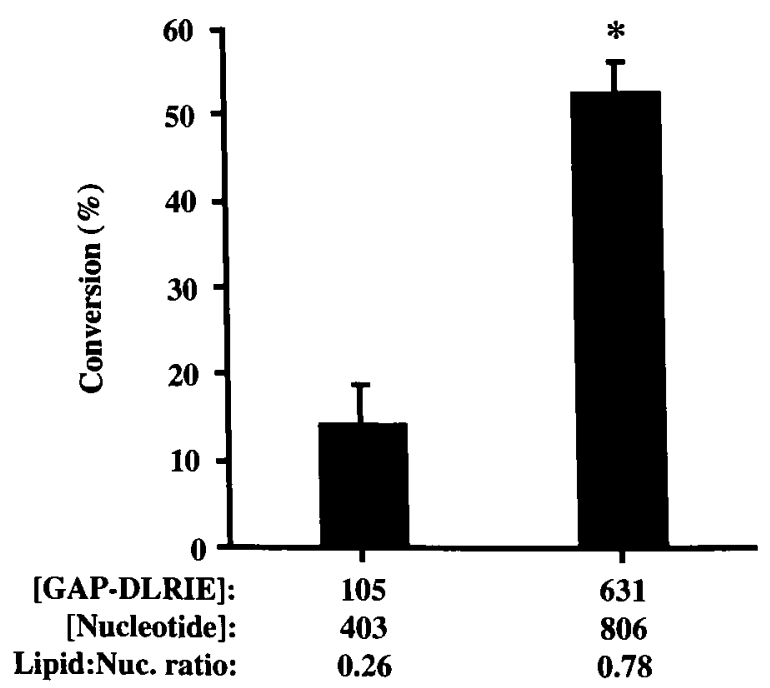

FIG. 3. Comparison of gene expression at 0.26 and $0.78 \mu M$ ratios of GAP-DLRIE/DOPE and nucleotide. Left. $n=5$ arteries. Right. $n=4$ arteries. Concentrations of GAP-DLRIE/ DOPE and nucleotide are indicated in $\mu M .{ }^{*} p<0.001$; unpaired, two-tailed Student's $t$-test. 
ance (ANOVA) followed by a Scheffe test. If the ANOVA demonstrated a $p<0.05$, then a $2 \times 2$ comparison was performed using an unpaired, two-tailed Student's $t$-test to determine the level of significance accounting for multiple comparisons.

\section{RESULTS}

\section{Optimization of the ratio of GAP-DLRIE/DOPE to DNA}

To determine the optimal ratio of lipid to DNA for arterial transfection, a plasmid expression vector encoding CAT regulated by a CMV enhancer/promoter (pCMV-CAT) was transfected into porcine arteries in vivo with GAP-DLRIE/DOPE. Increasing concentrations of GAP-DLRIE at the following doses: $105 \mu M(125 \mu \mathrm{g} / \mathrm{ml}), 158 \mu M(187.5 \mu \mathrm{g} / \mathrm{ml}), 316 \mu M$ $(375 \mu \mathrm{g} / \mathrm{ml})$, and $526 \mu M(625 \mu \mathrm{g} / \mathrm{ml})$ and DOPE, at an equimolar concentration, were tested with DNA held constant at $403 \mu M$ nucleotide $(125 \mu \mathrm{g} / \mathrm{ml})$, resulting in cationic lipid/nucleotide ratios of $0.26,0.39,0.78$, and 1.3 molar. Control experiments were performed with DNA at the same concentration $(403 \mu M)$ without lipid. Measurements of CAT activity were made in extracts from transfected iliofemoral arteries $48 \mathrm{hr}$ later. Transfection with pCMV-CAT without lipid resulted in $5.0 \pm 3.5 \%$ CAT conversion (Fig. 1). With this constant amount of DNA $(403 \mu M)$ and increasing lipid concentrations, CAT activity ranged from $4.75 \pm 1 \%$ to $24.5 \pm 19.6 \%$. The highest levels of gene expression were observed at 0.26 , 0.78 , and $1.3 \mathrm{molar}$ lipid/nucleotide ratios. The charge ratio for each cationic lipid/nucleotide ratio is also shown (Fig. 1). Because there are two positive charges per molecule of GAPDLRIE at physiological $\mathrm{pH}$, the electrovalent ratio is two times higher than the lipid/nucleotide ratio.

\section{Optimization of the concentration of GAP-DLRIEIDOPE and DNA}

To examine the effect of the concentration of GAP-DLRIE/DOPE and DNA complex on transfection efficiency in vivo, two lipid/nucleotide molar ratios were examined, 0.26 and 0.78 . There were no significant differences in percent CAT conversion with increasing GAP-DLRIE/DOPE:nucleotide concentrations at a 0.26 ratio $(p=\mathrm{NS})$ (Fig. 2A). In contrast, at a 0.78 ratio, increasing the concentration of GAP-DLRIE/DOPE:nucleotide resulted in a dose-dependent increase in gene expression, with maximal CAT activity reached with $631 \mu M(750 \mu \mathrm{g} / \mathrm{ml})$

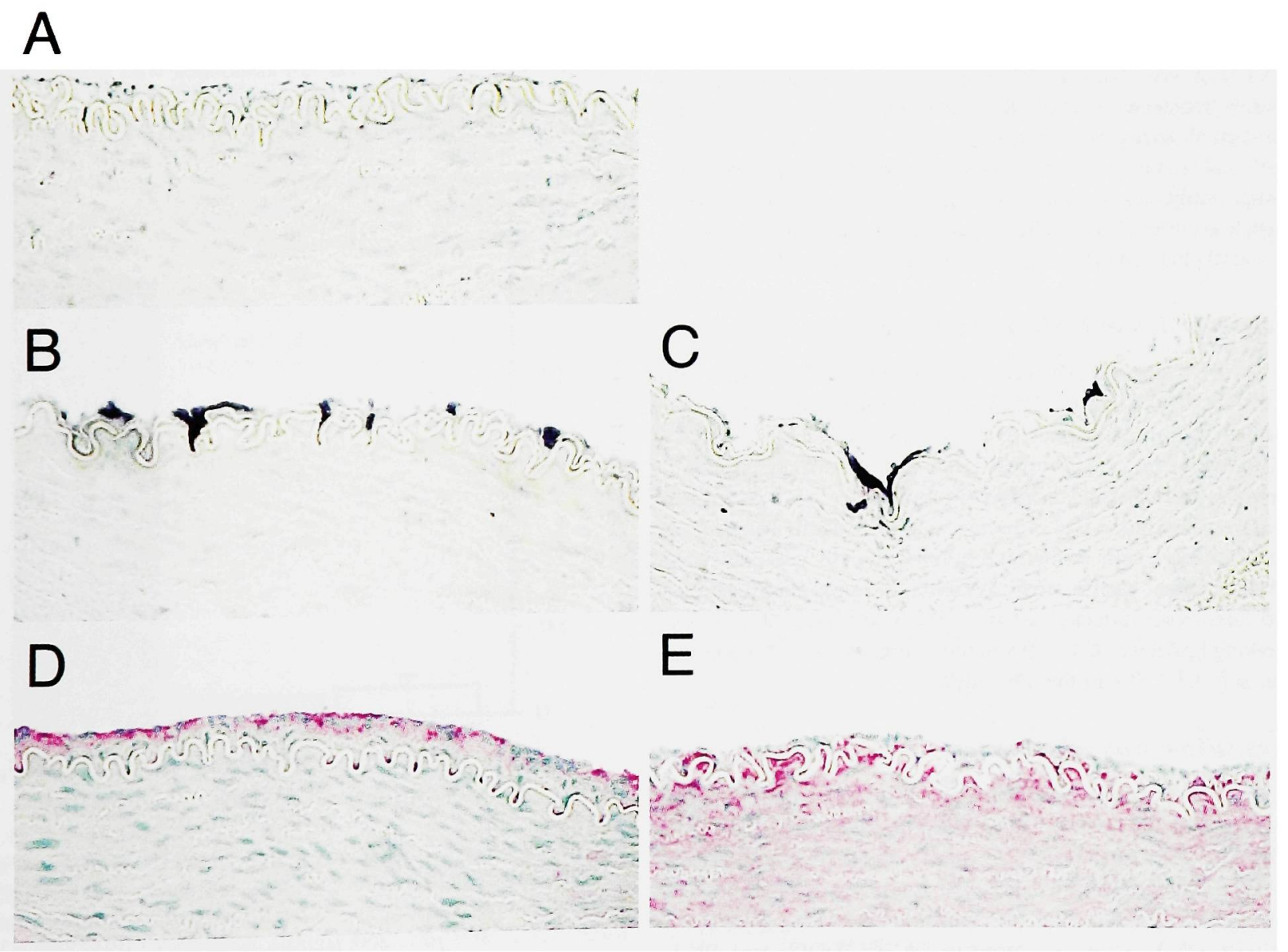

FIG. 4. Alkaline phosphatase expression in endothelial and smooth muscle cells in transfected porcine arteries. Microscopic sections were analyzed by histochemical staining in arteries transfected with GAP-DLRIE/DOPE and pCMV-CAT (A) or pCMV$\operatorname{hpAP}(B, C)$. Immunohistochemical analysis was performed with a monoclonal antibody for von Willebrand's factor (D) or smooth muscle $\alpha$-actin (E), identifying transfected cells as endothelial cells and smooth muscle cells. 
Table 2. Evaluation of Serum Enzymes Pre and 6 Weeks Post Three Intravenous Tail Vein InJections of SALINE (CONTROL) OR GAP DLRIE/DOPE AND DNA (EXPERIMENTAL) IN Mice

\begin{tabular}{|c|c|c|c|c|}
\hline & \multicolumn{2}{|c|}{ Control } & \multicolumn{2}{|c|}{ Experimental } \\
\hline & $\begin{array}{c}\text { Pre } \\
(\mathrm{n}=5)\end{array}$ & $\begin{array}{c}\text { Post } \\
(\mathrm{n}=5)\end{array}$ & $\begin{array}{c}\text { Pre } \\
(\mathrm{n}=5)\end{array}$ & $\begin{array}{c}\text { Post } \\
(\mathrm{n}=5)\end{array}$ \\
\hline Albumin (g/dl) & $2.5 \pm 0.2$ & $2.7 \pm 0.2$ & $2.3 \pm 0.2$ & $2.6 \pm 0.1$ \\
\hline Alkaline phosphatase (IU/1) & $185 \pm 9$ & $150 \pm 7$ & $165 \pm 16$ & $131 \pm 11$ \\
\hline Amylase (U/l) & $2559 \pm 102$ & $2885 \pm 165$ & $2385 \pm 60$ & $2534 \pm 130$ \\
\hline Bilirubin (mg/dl) & $0.6 \pm 0.2$ & $0.1 \pm 0.1$ & $0.5 \pm 0.1$ & $0.1 \pm 0.1$ \\
\hline $\mathrm{BUN}(\mathrm{mg} / \mathrm{dl})$ & $22 \pm 2$ & $22 \pm 3$ & $22 \pm 1$ & $21 \pm 2$ \\
\hline Calcium (mg/dl) & $7.6 \pm 0.5$ & $9.4 \pm 0.3$ & $7.0 \pm 0.4$ & $9.0 \pm 0.2$ \\
\hline Chloride $(\mathrm{mEq} / \mathrm{l})$ & $109 \pm 3$ & $115 \pm 2$ & $119 \pm 3$ & $115 \pm 1$ \\
\hline Cholesterol (mg/dl) & $88 \pm 9$ & $78 \pm 4$ & $76 \pm 9$ & $72 \pm 4$ \\
\hline Creatinine (mg/dl) & $0.5 \pm 0.1$ & $0.4 \pm 0.1$ & $0.4 \pm 0.1$ & $0.3 \pm 0.2$ \\
\hline GGT (IU//) & $23 \pm 3$ & $24 \pm 1$ & $21 \pm 4$ & $21 \pm 1$ \\
\hline Glucose (mg/dl) & $181 \pm 20$ & $159 \pm 9$ & $231 \pm 30$ & $153 \pm 12$ \\
\hline Sodium $(\mathrm{mEq} / \mathrm{l})$ & $160 \pm 3$ & $155 \pm 2$ & $164 \pm 2$ & $149 \pm 1$ \\
\hline Phosphorus (mg/dl) & $7.5 \pm 0.9$ & $4.8 \pm 0.5$ & $8.3 \pm 0.8$ & $6.7 \pm 0.3$ \\
\hline Potassium (mEq/l) & $5.8 \pm 0.4$ & $3.9 \pm 0.1$ & $7.0 \pm 0.5$ & $4.3 \pm 0.3$ \\
\hline SGOT (IU/I) & $77 \pm 3$ & $76 \pm 10$ & $57 \pm 5$ & $69 \pm 21$ \\
\hline SGPT (IU/l) & $26 \pm 5$ & $11 \pm 2$ & $21 \pm 2$ & $13 \pm 2$ \\
\hline Triglycerides (mg/dl) & $112 \pm 13$ & $76 \pm 7$ & $84 \pm 12$ & $65 \pm 11$ \\
\hline Total protein $(\mathrm{G} / \mathrm{dl})$ & $4.9 \pm 0.5$ & $4.5 \pm 0.5$ & $4.1 \pm 0.2$ & $4.2 \pm 0.2$ \\
\hline Total globulin $(\mathrm{g} / \mathrm{dl})$ & $2.4 \pm 0.5$ & $1.5 \pm 0.2$ & $1.8 \pm 0.2$ & $1.3 \pm 0.1$ \\
\hline
\end{tabular}

Data are expressed as mean \pm SEM.

plexes used. In previous studies, high concentrations of DNA-liposome complexes led to aggregation and toxicity following intravenous injection in mice in vivo (Stewart et al., 1992). Newer formulations have proven less toxic, allowing concentrations up to 1,000 -fold higher than those used previously (San et al., 1993). When using the 0.78 molar ratio, increasing concentrations of lipid and DNA produce a dose-re- sponse curve that reached an optimum at $803 \mu M$ DNA. The decrease in transfection efficiency at higher concentrations may be the result of aggregation of the complexes, given the high amount of lipid used. Although it is possible that the DNA-liposome complex could exert a toxic effect on arterial cells, we did not observe increased toxicity in arteries transfected with GAP-DLRIE/DOPE compared with arteries

Table 3. Histological analysis of Tissue Following Introduction of DNA-Liposomes In Vivo

\begin{tabular}{|c|c|c|c|c|}
\hline \multirow{3}{*}{$\begin{array}{l}\text { Number of injections: } \\
\text { Day of sacrifice: } \\
\text { Treatment: } \\
\text { (Number) }\end{array}$} & \multicolumn{2}{|c|}{1} & \multicolumn{2}{|c|}{1} \\
\hline & \multicolumn{2}{|c|}{14 days } & \multicolumn{2}{|c|}{42 days } \\
\hline & $\begin{array}{l}\text { Control } \\
(\mathrm{n}=5)\end{array}$ & $\begin{array}{c}\text { DNA/liposome } \\
(\mathrm{n}=5)\end{array}$ & $\begin{array}{l}\text { Control } \\
(\mathrm{n}=5)\end{array}$ & $\begin{array}{c}\text { DNA/liposome } \\
(\mathrm{n}=5)\end{array}$ \\
\hline Heart & Normal & Normal $^{a}$ & Normal & Normal $^{a}$ \\
\hline Lung & Normal & Normal $^{b}$ & Normal & Normal ${ }^{b}$ \\
\hline Liver & Normal ${ }^{\mathrm{c}}$ & Normal $^{c}$ & Normal & Normal $^{b}$ \\
\hline Kidney & Normal & Normal & Normal & Normal \\
\hline Spleen & Normal & Normal & Normal & Normal \\
\hline Skeletal muscle & Normal & Normal & Normal & Normal \\
\hline Ovary & Normal $^{\mathrm{d}}$ & Normal $^{\text {d }}$ & Normal ${ }^{\mathrm{d}, \mathrm{e}}$ & Normal \\
\hline Brain & Normal & Normal & Normal & Normal \\
\hline
\end{tabular}

Control injection (lactated Ringer's solution) or DNA-liposome complex (GAP-DLRIE/DOPE) + DNA were performed as described in Tables 1 and 2 legends. aEpicardial calcifications were observed in one of the five samples; these are minor pathologic changes of
no clinical significance.

bo data are available for one of the five samples.

${ }^{c}$ A rare cluster of mononuclear inflammatory cells was observed in one of the five samples; these are minor pathologic changes of no clinical significance.

'There was no ovary in one of the five samples.

${ }^{e}$ One of the five samples of Fallopian tube displayed very acute inflammatory infiltrate without necrosis;
is pathology is unlikely to be related to the treatment 


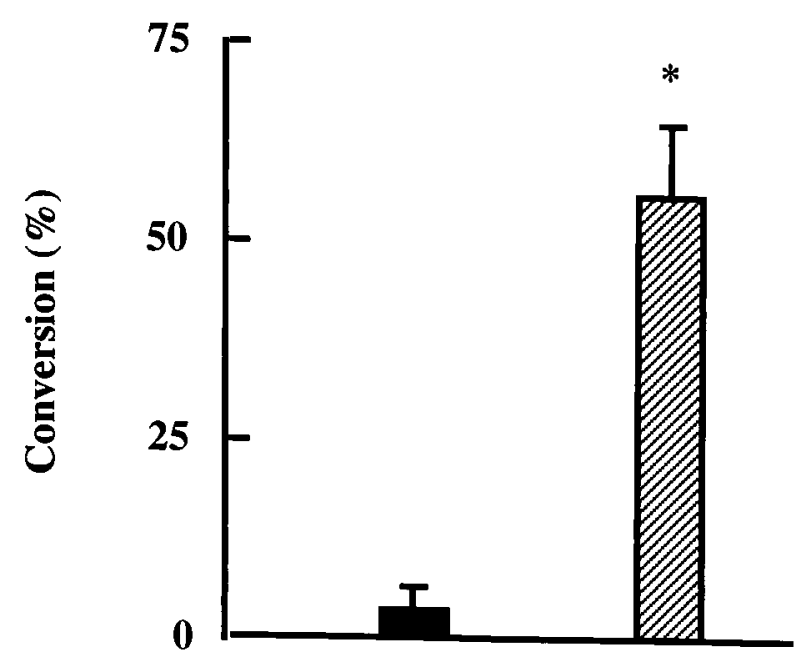

\section{GAP-DLRIE ADV DNA}

FIG. 6. Comparison of percent CAT conversion in transfected arteries with optimal concentrations following adenoviral infection $\left(7 \times 10^{9} \mathrm{pfu}\right)$ and GAP-DLRIE/DOPE and DNA (0.78 molar ratio). $n=3$ arteries in each group * $p<0.001$, unpaired, two-tailed Student's $t$-test.

and DNA causes toxicity to major organ systems in vivo, serum biochemical parameters and histopathology were evaluated in three groups of mice. In group l ( $n=4$ mice), CAT activity was detected in spleen, but not heart, lung, or kidney, 4 days after a single intravenous tail vein injection of GAPDLRIE/DOPE (30 $\mu \mathrm{g})$ and DNA $(10 \mu \mathrm{g})$. In group $2(n=10$ mice), saline or GAP-DLRIE/DOPE (30 $\mu \mathrm{g}$ ) and DNA (10 $\mu \mathrm{g})$ was injected into the tail vein and serum biochemistries and histopathology were examined 14 days later. No significant differences in serum enzymes were observed pre- and post-treatment in either group, and major organ pathology was not present (Tables 1 and 3$)$. In group $3(n=10$ mice), single injections of saline or GAP-DLRIE/DOPE (30 $\mu \mathrm{g})$ and DNA (10 $\mu \mathrm{g})$ were given at 2-week intervals for 6 weeks (three injections total). Serum biochemical abnormalities and major organ pathology were not observed (Tables 2 and 3 ).

\section{DISCUSSION}

In this study, we have evaluated and determined an optimal lipid/nucleotide ratio and concentration of a new cationic lipid, GAP-DLRIE/DOPE, for arterial gene transfer in vivo. We found that transfection of arteries with a 0.78 molar ratio of GAP-DLRIE/DOPE $(631 \mu M, 750 \mu \mathrm{g} / \mathrm{ml})$ and nucleotide (806 $\mu M, 250$ $\mu \mathrm{g} / \mathrm{ml}$ ) resulted in an approximate 15-fold higher level of CAT activity compared with DNA alone or another cationic lipid, DMRIE/DOPE. However, when compared with adenoviral vectors $\left(7 \times 10^{9} \mathrm{pfu}\right)$, CAT activity with GAP-DLRIE/DOPE and DNA was approximately 20 -fold less. No significant biochemical abnormalities or organ toxicities were observed following intravenous injection of GAP-DLRIE/DOPE and DNA. This new cationic lipid formulation, when optimized for gene transfer efficiency in vivo, provides a significant improvement in gene expression compared with other nonviral vectors and begins to approach the range of efficacy observed with adenoviral vectors (titers $\leq 10^{9} \mathrm{pfu} / \mathrm{ml}$ ).

One of the limitations of lipsome-mediated gene transfer is the relatively low concentration of DNA-liposome com-

Table 1. Evaluation of Serum Enzymes Pre and 14 Days Post a Single Intravenous tall Vein INJECTION OF SALINE (CONTROL) OR GAP DLRIE/DOPE AND DNA (EXPERIMENTAL) IN Mice

\begin{tabular}{|c|c|c|c|c|}
\hline & \multicolumn{2}{|c|}{ Control } & \multicolumn{2}{|c|}{ Experimental } \\
\hline & $\begin{array}{c}\text { Pre } \\
(\mathrm{n}=5)\end{array}$ & $\begin{array}{c}\text { Post } \\
(\mathrm{n}=5)\end{array}$ & $\begin{array}{c}\text { Pre } \\
(\mathrm{n}=5)\end{array}$ & $\begin{array}{c}\text { Post } \\
(\mathrm{n}=5)\end{array}$ \\
\hline Albumin $(\mathrm{g} / \mathrm{dl})$ & $2.5 \pm 0.2$ & $3.3 \pm 0.2$ & $2.5 \pm 0.2$ & $3.2 \pm 0.2$ \\
\hline Alkaline phosphatase (IU/l) & $155 \pm 14$ & $138 \pm 18$ & $177 \pm 23$ & $143 \pm 8$ \\
\hline Amylase (U/I) & $2511 \pm 216$ & $2621 \pm 196$ & $2391 \pm 191$ & $2372 \pm 76$ \\
\hline Bilirubin (mg/dl) & $0.6 \pm 0.2$ & $0.3 \pm 0.1$ & $0.6 \pm 0.1$ & $0.6 \pm 0.1$ \\
\hline $\mathrm{BUN}(\mathrm{mg} / \mathrm{dl})$ & $20 \pm 2.4$ & $23 \pm 1.9$ & $24 \pm 2.1$ & $20.4 \pm 2$ \\
\hline Calcium (mg/dl) & $6.6 \pm 0.4$ & $9.7 \pm 0.2$ & $7.2 \pm 0.4$ & $9.5 \pm 0.4$ \\
\hline Chloride $(\mathrm{mEq} / \mathrm{l})$ & $109 \pm 2.5$ & $121 \pm 4.0$ & $119 \pm 2.5$ & $119 \pm 1.0$ \\
\hline Cholesterol (mg/dl) & $94 \pm 5$ & $64 \pm 6$ & $74 \pm 9$ & $63 \pm 6$ \\
\hline Creatinine $(\mathrm{mg} / \mathrm{dl})$ & $0.4 \pm 0.08$ & $0.4 \pm 0.12$ & $0.3 \pm 0.02$ & $0.7 \pm 0.02$ \\
\hline GGT (IU//) & $27 \pm 2.4$ & $16 \pm 4.5$ & $29 \pm 7.0$ & $24 \pm 2.0$ \\
\hline Glucose (mg/dl) & $183 \pm 14$ & $155 \pm 18$ & $209 \pm 29$ & $155 \pm 10$ \\
\hline Sodium $(\mathrm{mEq} / \mathrm{l})$ & $160 \pm 3$ & $162 \pm 4$ & $162 \pm 2$ & $159 \pm 1$ \\
\hline Phosphorus (mg/dl) & $9.3 \pm 1.2$ & $7.1 \pm 1.2$ & $8.9 \pm 0.2$ & $5.9 \pm 0.4$ \\
\hline Potassium (mEq/1) & $8.8 \pm 1.0$ & $5 \pm 0.3$ & $8.4 \pm 1.0$ & $4.3 \pm 0.1$ \\
\hline SGOT (IU/l) & $89 \pm 11$ & $135 \pm 22$ & $75 \pm 20$ & $99 \pm 25$ \\
\hline SGPT (IU/1) & $38 \pm 4$ & $21 \pm 3$ & $16 \pm 2$ & $18 \pm 1$ \\
\hline Triglycerides (mg/dl) & $106 \pm 7$ & $82 \pm 5$ & $94 \pm 5$ & $77 \pm 3$ \\
\hline Total protein $(\mathrm{G} / \mathrm{dl})$ & $4.1 \pm 0.3$ & $4.8 \pm 0.3$ & $4.3 \pm 0.4$ & $4.3 \pm 0.2$ \\
\hline Total globulin $(\mathrm{g} / \mathrm{dl})$ & $1.6 \pm 0.2$ & $1.5 \pm 0.2$ & $1.8 \pm 0.2$ & $1.1 \pm 0.2$ \\
\hline
\end{tabular}

Data are expressed as mean $\pm S E M$. 
LEW, D., PARKER, S.E., LATIMER, T. ABAI, A.M., KUWAHARARUNDELL, A., DOH, S.G., YANG, Z.Y., LAFACE, D., GROMKOWSKI, S.H., and NABEL, G.J. (1995). Cancer gene therapy using plasmid DNA: pharmacokinetic study of DNA following injection in mice. Hum. Gen. Ther. 6, 553-564.

MANTHORPE, M., COMEFERT-JENSEN, F., HARTIKKA, J., FELGNER, J.H., RUNDELL, A., MARGALITH, M., and DWARKI, V. (1993). Gene therapy by intramuscular injection of plasmid DNA: Studies on firefly luciferase gene expression in mice. Hum. Gen. Ther. 4, 419-431.

MULLER, D.W.M., GORDON, D., SAN, H., YANG, Z.Y., POMPILI, V.J., NABEL, G.J., and NABEL, E.G. (1994). Catheter-mediated pulmonary vascular gene transfer and expression. Circ. Res. 75, $1039-1049$.

NABEL, E.G., PLAUTZ, G., and NABEL, G.J. (1990). Site-specific gene expression in vivo by direct gene transfer into the arterial wall. Science 249, 1285-1288.

NABEL, E.G., YANG, Z.Y., PLAUTZ, G., FOROUGH, R., XI, Z., HAUDENSCHMIDT, C.C., and NABEL, G.J. (1993). Recombinant fibroblast growth factor-1 promotes intimal hyperplasia and angiogenesis. Nature 362, 844-846.

NABEL, E.G., YANG, Z.Y., MULLER, D., CHANG, A.E., GAO, X., HUANG, L., CHO, K.J., and NABEL, G.J. (1994). Safety and toxicity of catheter gene delivery to the pulmonary vasculature in a patient with metastatic melanoma. Hum. Gen. Ther. 5, 1089-1094.

NABEL, E.G. (1995). Gene therapy for cardiovascular disease. Circulation 91, 541-548.

NABEL, G.J., NABEL, E.G., YANG, Z.Y., FOX, B.A., PLAUTZ, G.E., GAO, X., HUANG, L., SHU, S., GORDON, D., and CHANG, A. (1993). Direct gene transfer with DNA-liposome complexes in melanoma: expression, biologic activity, and lack of toxicity in humans. Proc. Natl. Acad. Sci. USA 90, 11307-11311.

OHNO, T., GORDON, D., SAN, H., POMPILI, V.J., IMPERIALE, M.J., NABEL, G.J., and NABEL, E.G. (1994). Gene therapy for vascular smooth cell proliferation after arterial injury. Science $\mathbf{2 6 5}$, 781-784.

POMPILI, V.J., GORDON, D., SAN H., YANG, Z., MULLER, D.W.M., NABEL, G.J., and NABEL, E.G. (1995). Expression and function of a recombinant PDGF $B$ gene in porcine arteries. Arterioscler. Thromb. Vasc. Biol. 15, 2254-2264.

SAN, H., YANG, Z.Y., POMPZII, V.J., PLAUTZ, G., XU, L., FELGNER, P.L., GAO, X., HUANG, L., GORDON, D., NABEL, G.J., and NABEL, E.G. (1993). Safety and toxicity of a novel cationic lipid formulation of human gene therapy. Hum. Gene Ther. 4, 781-788.

SHI, Y., FARD, A., VERMANI, P., and ZALEWSKI, A. (1994). Transgene expression in the coronary circulation: transcatheter gene delivery. Gene Ther. 1, 408-414.
SIMARI, R.D., SAN, H., REKHTER M., OHNO, T. GORDON, D., NABEL, G.J., and NABEL, E.G. (1996a). Regulation of cellular proliferation and intimal formation following balloon injury in atherosclerotic rabbit arteries. J. Clin. Invest. 98, 225-235.

SIMARI, R.D., SAN, H., and NABEL, E.G. (1996b). Gene transfer to arteries. In: Current Protocols in Human Genetics (John Wiley and Sons, New York)

SIMON, R.H., ENGLEHARDT, J.F., YANG, Y., ZEPEDA, M., WEBER-PENDELTON, S., GROSSMAN, M., and WLSON, J.M. (1993). Adenovirus-mediated gene transfer of the CFTR gene to lung of nonhuman primates: A toxicity study. Hum. Gene Ther. 4, 771-780.

STEG, P.G, FELDMAN, L.J., SCOAZEC, J.Y., TAHILIL, O., BARRY, J.J., BOULECHFAR, S., RAGOT, T., ISNER, J.M., and PERRICAUDET, M. (1994). Afterial gene transfer to rabbit endothelial and smooth muscle cells using percutaneous delivery of an adenoviral vector. Circulation 90, 1648-1656.

STEWART, M.J., PLAUTZ, G.E., BUONO, L.D., YANG, Z.Y., GAO, X., HUANG, L., NABEL, E.G., and NABEL, G.J. (1992). Gene transfer in vivo with DNA-liposome complexes: Safety and acute toxicity in mice. Hum. Gene Ther. 3, 267-275.

WHEELER, C.J., FELGNER, P.L., TSAI, Y.J., MARSHALL, J., SUKHU, L., DOH, G., HARTIKKA, J., NIETUPSKI, J., MANTHORPE, M., NICHOLS, M., PLEWE, M., LIANG, X., NORMAN, J., SMITH, A., and CHENG, S.H. (1996). A novel cationic lipid greatly enhances plasmid DNA delivery and expression in mouse lung. Proc. Natl. Acad. Sci. USA (in press).

YANG, Z.Y., NUNES, F.A., BERENCSI, K., FURTH, E.E., GONCZOL, E., and WILSON, J.M. (1994). Cellular immunity to viral antigens limits E1-deleted adenoviruses for gene therapy. Proc. Natl. Acad. Sci. USA 91, 4407-4411.

Y $\overline{A N G, ~ Z . Y ., ~ P E R K I N S, ~ N . D ., ~ S I M A R I, ~ R . D ., ~ S A N, ~ H . ~ G O R D O N, ~}$ D., NABEL, G.J., and NABEL, E.G. (1996). Role of the p21 cyclin-dependent kinase inhibitor in limting intimal cell proliferation in response to arterial injury. Proc. Natl. Acad. Sci. USA 93, 7905-7910.

Address reprint requests to: Dr. Elizabeth G. Nabel University of Michigan 7301 MSRB III

1150 W. Medical Center Drive Ann Arbor, MI 48109-0644

Received for publication January 23, 1996; accepted July 8, 1996. 
This article has been cited by:

1. D M Mahvi, M B Henry, M R Albertini, S Weber, K Meredith, H Schalch, A Rakhmilevich, J Hank, P Sondel. 2007. Intratumoral injection of IL-12 plasmid DNA - results of a phase I/IB clinical trial. Cancer Gene Therapy 14:8, 717-723. [CrossRef]

2. Wen-Chi Tseng, Chien-Hsiang Tang, Tsuei-Yun Fang, Ling-Yu Su. 2007. Using disaccharides to enhancein vitro andin vivo transgene expression mediated by a lipid-based gene delivery system. The Journal of Gene Medicine 9:8, 659-667. [CrossRef]

3. Takaaki Sato, Takehiro Serikawa, Masayuki Sekine, Yoichi Aoki, Kenichi Tanaka. 2005. Increased efficiency of cisplatin-resistant cell lines to DNA-mediated gene transfer with cationic liposome. Journal of Obstetrics and Gynaecology Research 31:5, 368-374. [CrossRef]

4. R. C. Smith, K. Walsh. 2001. Local gene delivery to the vessel wall. Acta Physiologica Scandinavica 173:1, 93-102. [CrossRef]

5. Lorena Baccaglini, A. T. M. Shamsul Hoque, Robert B. Wellner, Corinne M. Goldsmith, Robert S. Redman, Vidya Sankar, Albert Kingman, Kerry M. Barnhart, Carl J. Wheeler, Bruce J. Baum. 2001. Cationic liposome-mediated gene transfer to rat salivary epithelial cellsin vitro andin vivo. The Journal of Gene Medicine 3:1, 82-90. [CrossRef]

6. Birgit Kantor, John Altman, Robert S. Simari, Antonio Bayes-Genis, Paul J. Keelan, David R Holmes, Robert S. Schwartz. 2000. Gene therapy for myocardial angiogenesis: Has it come of age?. Current Atherosclerosis Reports 2:5, 373-379. [CrossRef]

7. Shao-Min Zou, Patrick Erbacher, Jean-Serge Remy, Jean-Paul Behr. 2000. Systemic linear polyethylenimine (L-PEI)-mediated gene delivery in the mouse. The Journal of Gene Medicine 2:2, 128-134. [CrossRef]

8. María José Fonseca, Gert Storm, Wim E. Hennink, Winald R. Gerritsen, Hidde J. Haisma. 1999. Cationic polymeric gene delivery of $\beta$-glucuronidase for doxorubicin prodrug therapy. The Journal of Gene Medicine 1:6, 407-414. [CrossRef]

9. Charles L. Densmore, Thomas H. Giddings, J. Clifford Waldrep, Berma M. Kinsey, Vernon Knight. 1999. Gene transfer by guanidinium-cholesterol: dioleoylphosphatidyl-ethanolamine liposome-DNA complexes in aerosol. The Journal of Gene Medicine 1:4, 251-264. [CrossRef]

10. Akira Kikuchi, Yoichi Aoki , Susumu Sugaya , Takehiro Serikawa, Koichi Takakuwa , Kenichi Tanaka , Norio Suzuki , Hiroshi Kikuchi . 1999. Development of Novel Cationic Liposomes for Efficient Gene Transfer into Peritoneal Disseminated TumorDevelopment of Novel Cationic Liposomes for Efficient Gene Transfer into Peritoneal Disseminated Tumor. Human Gene Therapy 10:6, 947-955. [Abstract] [PDF] [PDF Plus]

11. Nikolai G. Rainov, Keiro Ikeda , Nazir H. Qureshi , Shivani Grover, Ulrich Herrlinger , Peter Pechan , E. Antonio Chiocca , Xandra O. Breakefield, Faith H. Barnett . 1999. Intraarterial Delivery of Adenovirus Vectors and Liposome-DNA Complexes to Experimental Brain NeoplasmsIntraarterial Delivery of Adenovirus Vectors and Liposome-DNA Complexes to Experimental Brain Neoplasms. Human Gene Therapy 10:2, 311-318. [Abstract] [PDF] [PDF Plus]

12. Andrew D. Miller. 1998. Kationische Liposomen für die Gentherapie. Angewandte Chemie 110:13-14, 1862-1880. [CrossRef]

13. Marilyn E. Ferrari, Cuong M. Nguyen, Olivier Zelphati, Yali Tsai, Philip L. Felgner. 1998. Analytical Methods for the Characterization of Cationic Lipid-Nucleic Acid ComplexesAnalytical Methods for the Characterization of Cationic Lipid-Nucleic Acid Complexes. Human Gene Therapy 9:3, 341-351. [Abstract] [PDF] [PDF Plus]

14. Suezanne E. Parker, Sylvie Ducharme, Jon Norman, Carl J. Wheeler. 1997. Tissue Distribution of the Cytofectin Component of a Plasmid-DNA/Cationic Lipid Complex Following Intravenous Administration in MiceTissue Distribution of the Cytofectin Component of a Plasmid-DNA/Cationic Lipid Complex Following Intravenous Administration in Mice. Human Gene Therapy 8:4, 393-401. [Abstract] [PDF] [PDF Plus] 